\title{
POSTIRRADIATION INSPECTION OF SUBASSEMBLIES DISCHARGED \\ FROM RUNS 25 AND 26 IN EBR-II
}

\section{By}

R. R. Smith and D. Lo Mitchell

\author{
EBR-II Project \\ Argonne National Laboratory \\ Argonne, Illinois - Idaho Falls, Idaho
}

March 1969

Work performed under the auspices of the U. S. Atomic Energy Commission LEGAL NOTICE

This report was prepared as an account of Goverument aponsored work. Netther the United States, nor the Commission, nor any person acting on behalf of the Commiselon:

A. Makes any warranty or representation, expressed or implied, with respect to the accuracy, completenoss, or uaefuliness of the information contained in this report, or that the use privately arred righte; on

B. Assumes any liabilities with reapect to the use of, or for demages resulting from the of any taformation, apperatus, method, or process disclosed in this report.

As used in the above, "person acting on behalf of the Commiaston" Includer any em-

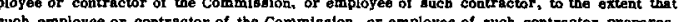
ataneming disaeminates, or provides acceas to, any Informattion purscant to bis employment or contract 


\section{DISCLAIMER}

This report was prepared as an account of work sponsored by an agency of the United States Government. Neither the United States Government nor any agency Thereof, nor any of their employees, makes any warranty, express or implied, or assumes any legal liability or responsibility for the accuracy, completeness, or usefulness of any information, apparatus, product, or process disclosed, or represents that its use would not infringe privately owned rights. Reference herein to any specific commercial product, process, or service by trade name, trademark, manufacturer, or otherwise does not necessarily constitute or imply its endorsement, recommendation, or favoring by the United States Government or any agency thereof. The views and opinions of authors expressed herein do not necessarily state or reflect those of the United States Government or any agency thereof. 


\section{DISCLAIMER}

Portions of this document may be illegible in electronic image products. Images are produced from the best available original document. 
? . 
TABLE OF CONTENTS

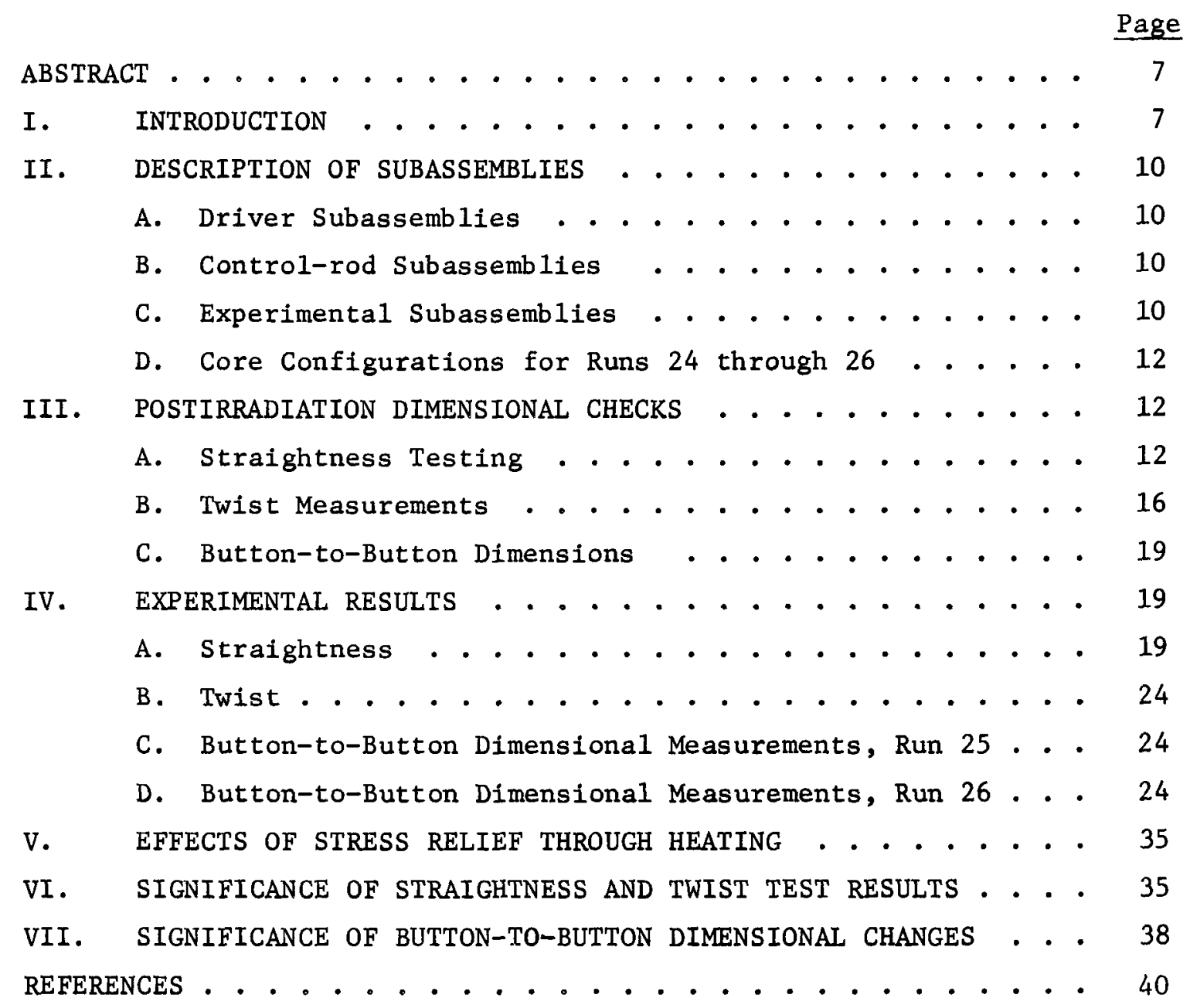


0 
No. Title Page

1. EBR-II Type Subassembly . . . . . . . . . . . . . 11

2. EBR-II Loading at End of Run 24 (Dec. 1966); 81-subassembly Core ....................... 13

3. EBR-II Loading for Run 25 (Apri1 17, 1967); 88-subassemb1y Core ......................... . 14

4. EBR-II Loading for Run 26C (Dec. 4, 1967); 91-subassemb1y Core . . . . . . . . . . . . . . . . . . 15

5. Orientation of Flats of Hex Tube . . . . . . . . . . . 17

6. Results of Straightness Measurements of Driver Subassemblies Discharged from Run 25 . . . . . . . . . . . . . . 23

7. Deviations Calculated from Button-to-Button Measurements, Run 25 . . . . . . . . . . . . . . . . . 36

8. Deviations Calculated from Button-to-Button Measurements, Run 26C . . . . . . . . . . . . . . . . . 37

\section{LIST OF TABLES}

No. Title

I. Results of Straightness Measurements of Driver Subassemblies Discharged from Run 25 . . . . . . . . . . . 20

II. Results of Straightness Measurements of Control Rods Discharged from Run 25 . . . . . . . . . . . . 22

III. Results of Twist Measurements of Driver and Control-rod Subassemblies Discharged from Run 25 . . . . . . . . . . 25

IV. Results of Button-to-Button Measurements of Driver Subassemblies Discharged from Run 25 . . . . . . . . . . 28

V. Results of Button-to-Button Measurements of Driver Subassemblies Discharged from Run 26 
$\bullet$

\section{,}




\section{POSTIRRADIATION INSPECTION OF SUBASSEMBLIES DISCHARGED \\ FROM RUNS 25 AND 26 IN EBR-II}

By

R。 R. Smith and D。 L. Mitchell

EBR-II Project

Argonne National Laboratory

Argonne, Illinois - Idaho Falls, Idaho

\section{$\underline{\text { ABSTRACT }}$}

The effects of bowing forces generated by stainless steel reflector subassemblies on driver subassemblies were investigated by making a series of dimensional checks on driver subassemblies discharged at the ends of Runs 25 and 26 in EBR-II. Postirradiation measurements were made of straightness, twist, and changes in dimensions across the spacer pads of opposite flats of the hexagonal tube of the driver subassemblies. The results of measurements of subassemblies discharged from Run 25 indicated no perceptible change in straightness or twist. The results of dimensional checks across the spacer pads of opposite flats, however, indicated an average decrease of $0.001_{2}$ in. per set of flats.

Straightness and twist tests were not made of subassemblies discharged from Run 26. The results of dimensional checks across the spacer pads of opposite flats of these subassemblies indicated a net decrease of $0.001_{2}$ in. per set of flats.

\section{INTRODUCTION}

To appreciate the importance of possible subassembly deformation effects in EBR-II during Run 25, it is instructive to review those events which led directly and indirectly to the Run-25 configuration: As additional irradiation experiments were added, the core gradually increased 
in effective radius. Since the power level was fixed at $45 \mathrm{MWt}$, as core size increased, the result was a gradual decrease in the power density of experiments. To remedy this undesirable effect and to avoid the frequent remapping of power distribution, it was decided to enlarge the core to some fixed reference condition which would remain relatively unchanged over the foreseeable future.

To implement this feature, six special subassemblies, each filled with a 50-50 complement of fuel elements and stainless steel dumy rods, were fabricated and installed in the core. As the results of calculations indicated, and as later demonstrated by experiment, each was worth approximately the same as an average experimental irradiation subassembly containing experimental fuel specimens. The objective at this time concerned the enlargement of the core to 89-91 subassemblies (91 being the maximum number)。Future experiment insertions would simply involve replacing a half-fueled driver subassembly with the experimental subassembly without requiring an adjustment of core outline. The actual change in loading involved an increase to 88 subassemblies from the 81 present in Run 24.

A more significant loading change for Run 25 concerned the inner two rows of the radial blanket. Since the results of surveillance measurements conducted on depleted-uranium blanket material indicated a potential swelling problem, it was decided to replace the first two rows ( 7 and 8 ) of the depleted-uranium blanket with stainless-steel-filled subassemblies. Aside from material differences, the latter were superficially identical with their uranium counterparts.

On startup of Run 25 on April 21, 1967, significant changes were noted in the power coefficient. Whereas Run 24 was characterized by a reasonably strong negative power coefficient over the range 0-45 MWt, the power coefficient for Run 25 was considerably weaker. Using the reactivity necessary to increase the power of the system from hot critical to operating power as a criterion, Run 24 was characterized by a power reactivity decrement ( $P R D$ ) of $0.00156 \Delta \mathrm{k} / \mathrm{k}$, and that associated with Run 25 amounted to only $0.00094 \Delta \mathrm{k} / \mathrm{k}$. Even more significant was the behavior of 
the power coefficient in the region 10-25 MWt. Whereas the slope of theRun-24 power coefficient in this power range was'strongly negative; that for Run 25 was weakly negative. Such behavior suggested that previously strong negative power-coefficient components in this power region were" either being weakened or were being partially cancelled by components that were positive.

The sizable decrease in power coefficient at the Run-24/Run-25 interface has been attributed, in large part, to the installation of the stainless steel reflector. Just how the stainless steel reflector affected the power coefficient has still not been established unambiguousiy, and in view of the difficulty of performing definitive in-core experiments, may never be established. Nevertheless, a model based on reversed subassembly bowing effects in Rows 7 and 8 subassemblies still- seems plausible in terms of what has been learned from detailed calculations of temperature distributions and subassembly bowing effects. $(1,2)$

It has been postulated that reverse bowing effects in the reflector have the effect of a spring which tends to force core subassemblies inward and blanket subassemblies outward. Although the results of simplified calculations clearly indicate the existence of the postulated reverse bowing, it is difficult to establish, with the degree of reliability needed, the extent and manifestations of the forces involved. It is conceivable that bowing forces may be sufficient to cause not only the elastic deformation of subassemblies, but a permanent inward deformation of the subassemblies in the vicinity of the spacer buttons as well. If either of these possibilities is true, core subassemblies would be subjected to larger inward displacements than those expected purely on the basis of design-clearances.

While in situ measurements of deformation effects"are virtually impossible to make, it is nevertheless possible to perform postirradiation. dimensional checks on discharged subassemblies:-Hence, if permanent deformation is indicated, it may safely be surmised that elastic or reversible deformational effects very likely exist. Accordingly, all 
subassemblies discharged from Runs 25 and 26 were subjected to a series of dimensional tests intended to resolve this very important question.

\section{DESCRIPTION OF SUBASSEMBLIES}

A. Driver Subassemblies

A diagram illustrating the pertinent features and dimensions- of a standard driver-fuel subassembly is given in Fig. 1. The subassembly consists essentially of a hexagonal stainless steel tube, 2.290 in. across external flats, with a 0.040 -in. wall. (3) The subassemblies are spaced in the reactor grid on a triangular pitch-of 2.320-in. center-tocenter distance A nominal clearance of 0.030 in. between subassemblies permits removal of the untts from the core. Each face of the subassembly is equipped with a button, 3/8 in。 in diameter and $0.014 \mathrm{in}$. in height, which is formed by dimpling the tube wall. The upper end fittings of all subassemblies in the core (driver, control rods, safety rods, and experiments) are identical. Standard driver subassemblies contain 91 Mark-IA fuel elements arranged in five hexagonal rows around the central element. Half-fueled subassemblies, on the other hand, contain 46 driver elements and 45 stainless steel dummy pins.

B. Control-rod Subassemblies

The control-rod subassemblies consist of a control rod and a guide thimble. The guide thimble is hexagonal in cross section and has the same dimensions as the hex tube of a conventional subassembly.

The control rod consists of a hexagonal tube, 1.908 in. across the flats, with a 0.040-1n, wall. All control and safety rods contain 61 standard Mark-IA driver-fuel elements arranged in four hexagonal rows around the central element

C. Experimental Subassemblies

Subassemblies containing experimental fuel or candidate cladding materials are superficially identical with standard driver subassemblies. Differences in orificing and internal details do exist, and these should be considered in any future detailed analysis of thermal-mechanical effects. 


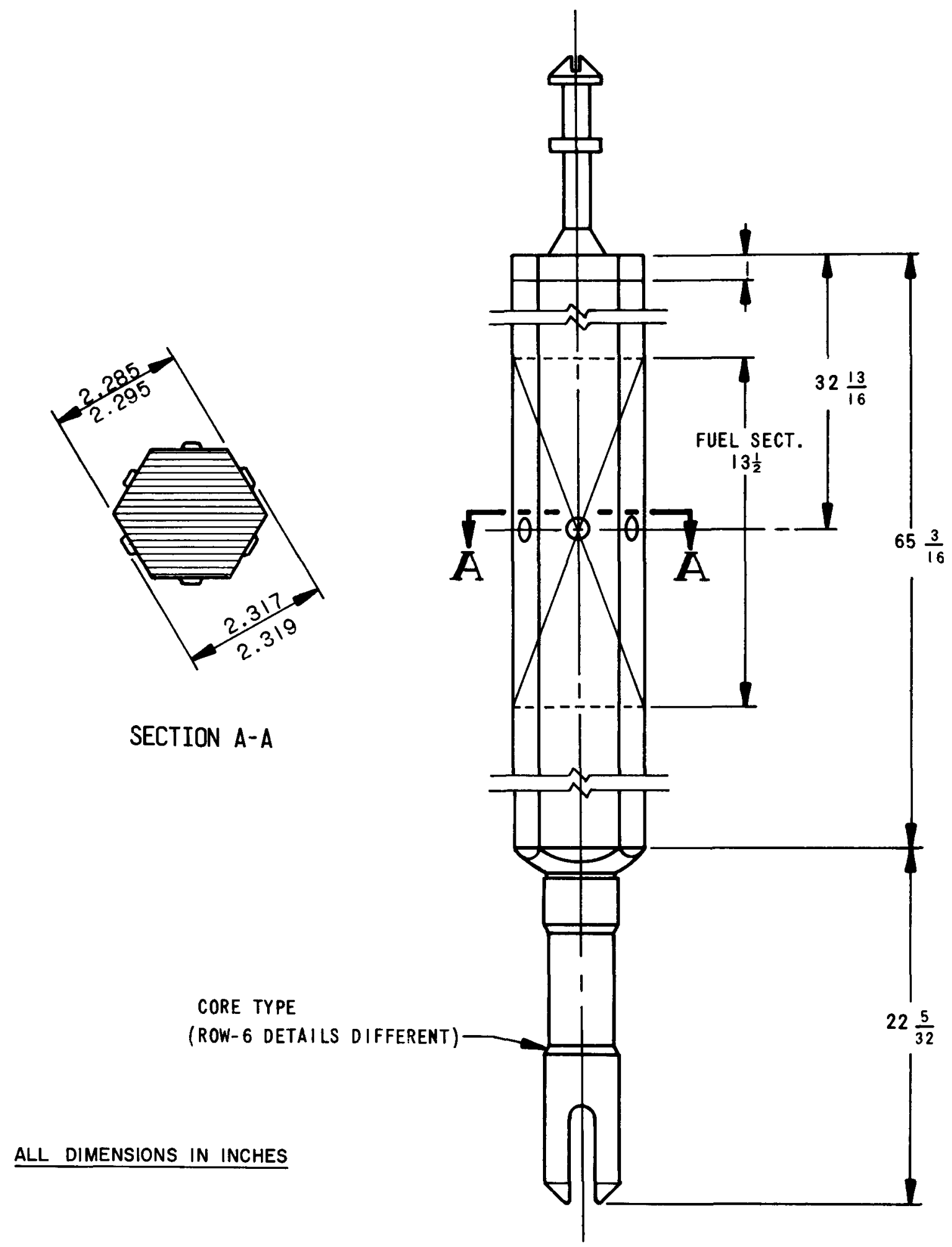

Fig. 1. EBR-II Type Subassembly 
D. Core Configurations for Runs 24 through 26

A pictorial inventory of all subassemblies (out through Row 8) at the end of Run 24 is given in Fig. 2. Similar inventories of subassemblies (out through Row 8) for Runs 25 and 26 are given in Figs. 3 and 4 , respectively.

\section{POSTIRRADIATION DIMENSIONAL CHECKS}

The following three basic types of measurements were performed on the discharged subassemblies: straightness, twist, and button-tobutton dimensions.

\section{A. Straightness. Testing}

In the straightness-testing rig, the subassembly is supported at the lower end of the bottom adapter and clamped at the upper and lower ends of the hex tubing. Six dial indicators are located along the length of the subassembly as described in step 2 below. The measurements are made as follows:

1. The subassembly is transferred to the straightness-testing rig with the cooled transfer grapple. The grapple remains in place on the subassembly to provide cooling during the measurements.

2. The subassembly is clamped into the straightness-testing rig, and the readings from the six dial indicators for the first flat (No。1) are recorded. The dial indicators are located at the following elevations:

\begin{tabular}{cc}
$\begin{array}{c}\text { Indicator } \\
\text { No. }\end{array}$ & $\begin{array}{c}\text { Distance from Top } \\
\text { of Hex Tube (in.) }\end{array}$ \\
\cline { 2 - 2 } 1 & 6.00 \\
2 & 19.25 \\
3 & 32.50 \\
4 & 45.875 \\
5 & 59.125 \\
6 & 72.50
\end{tabular}


NOTE: CONTROL ROD G-8 CONTAINS

OSCILLATOR ROD

$$
\begin{array}{ll}
\text { KEY: } & \text { D - DR IVER FUEL } \\
8 & -U \text { BLANKET } \\
\text { S - SAFETY ROD } \\
\text { C - CONTROL ROO } \\
\text { X - EXPERIMENTAL SUBASSEMBLY }
\end{array}
$$

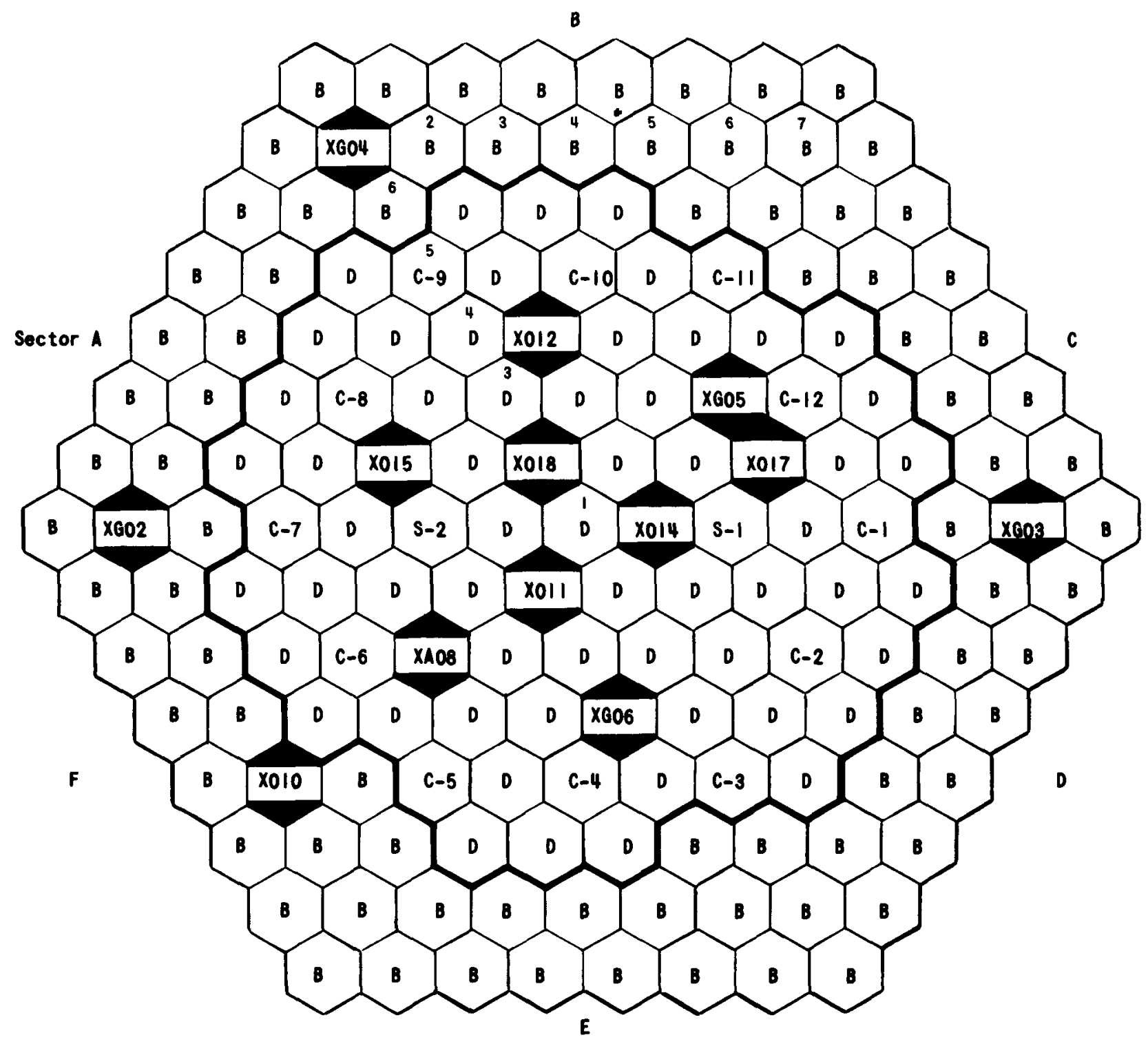

Fig. 2. EBR-II Loading at End of Run 24 (Dec. 1966);

81-subassembly Core 
NOTE: CONTROL ROD C-I

CONTAINS SS ONLY
KEY: D-ORIVER FUEL

R-SS REFLECTOR

S-SAFETY ROD

C- CONTROL ROD

$P-\frac{1}{2}$ DRIVER FUEL, $\frac{1}{2}$ SS

$X$-EXPERIMENTAL SUBASSEMBLY

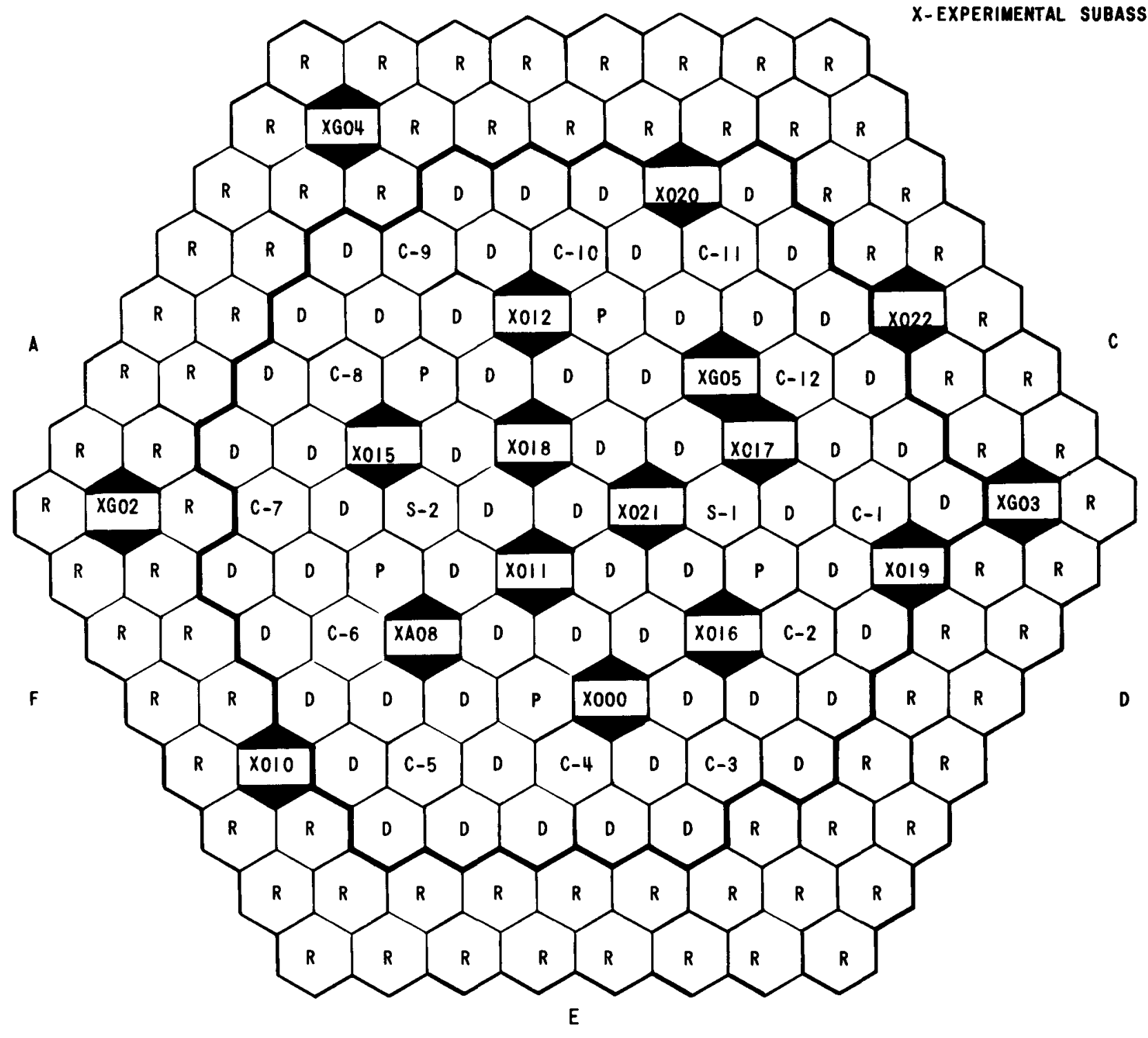

Fig. 3. EBR-II Loading for Run 25 (April 17, 1967);

88-subassemb1y Core 
NOTE:

CONTROL ROD C-I CONTAINS

SS CONTROL ROD

CONTROL ROD C.8 CONTAINS

OSCILLATOR ROD

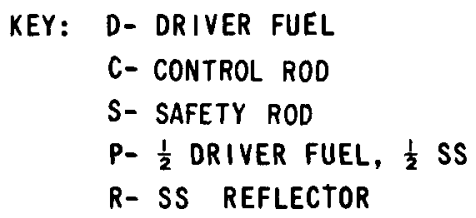

KEY: D- DRIVER FUEL

C- CONTROL ROD

S- SAFETY ROD

P- $\frac{1}{2}$ DRIVER FUEL, $\frac{1}{2}$ SS

$R$ - SS REFLECTOR

$X$ - EXPERIMENTAL SUBASSEMBLY

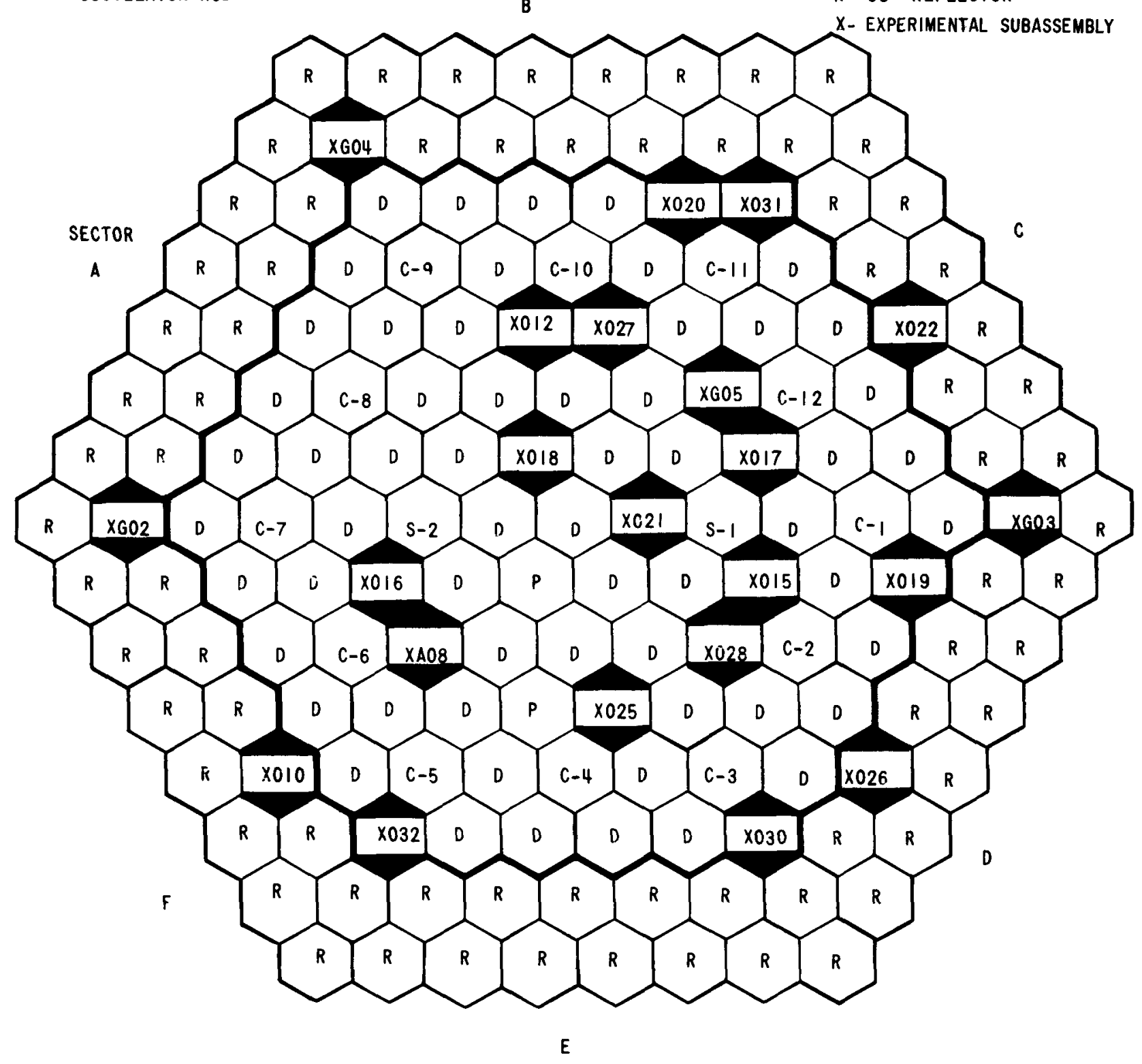

Fig. 4. EBR-II Loading for Run 26C (Dec. 4, 1967); 91-subassemb1y Core 
3. The clamps are released, the subassembly rotated $60^{\circ}$, the clamps reset, and the indicator readings recorded for flat No. 2. This procedure is repeated for all six flats.

4. From the tabulated data, the TIR (total Indicated runout) is calculated for each of the dial-indicator elevations given above. The TIR is the difference between the maximum indicated value for any flat and the minimum indicated value for any flat at the same elevation.

5. The subassembly is removed from the straightness-testing rig and placed in the vertical assembler-disassembler (VAD).

The significance of straightness measurements is essentially this: The TIR constitutes an effective index for the extent of deviation from the vertical at each of the above elevations.

\section{B. Twist Measurements}

The twist of the hex tube is measured with a dial indicator that gives two sets of readings, one set at each end of the hex while the subassembly is rigidly held in the VAD. For example, to measure the twist of flat No. 3, a dial indicator is placed on a platform that moves parallel to the C-D surface (see Fig。 5). The subassembly is positioned with the dial indicator approximately 2 in. up from the bottom of the hex tube and slightly to the right of position $C$. The reading is then recorded. The indicator and platform are then moved to the right and a reading taken just to the left of position D. For example, a typical set of readings may be " $\mathrm{C} "=0.002$ in. and " $\mathrm{D}$ " $=0.002$ in。 The subassembly is lowered into the VAD until the dial indicator is about 3 in. from the top of the hex. Again the indicator is moved from C to D. As an example, "C" = 0.007 in。 and "D" = 0.020 in. Hence,

\begin{tabular}{|c|c|c|c|}
\hline $\begin{array}{c}\text { Flat No. } \\
3\end{array}$ & $\begin{array}{l}\text { "C" } \\
\text { (in.) } \\
\end{array}$ & $\begin{array}{l}\text { "D" } \\
\text { (in.) } \\
\end{array}$ & $\begin{array}{l}\text { Twist } \\
\text { (in.) } \\
\end{array}$ \\
\hline Bottom & 0.002 & 0.002 & \\
\hline Top & 0.007 & 0.020 & 0.013 \\
\hline
\end{tabular}

In this particular example the indicator and platform did not move with respect to the subassembly centerline, and the subassembly did not rotate. The two readings at the bottom of the flat were the same $(0.002 \mathrm{in.})$, 


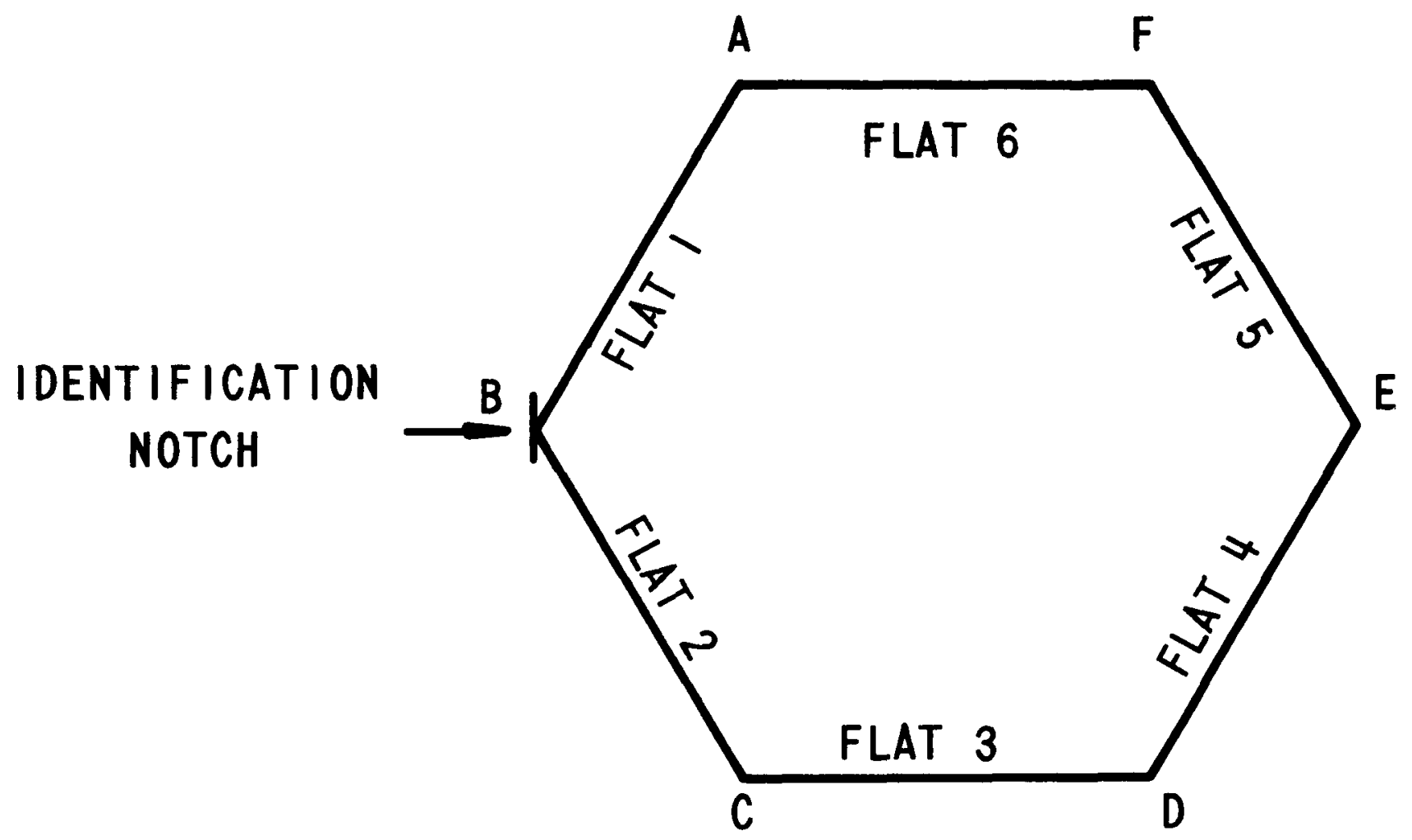

Fig. 5. Orientation of Flats of Hex Tube 
but the two readings at the top of the flat were 0.007 to 0.020 in. This indicates a twist in the hex tube of $0.013 \mathrm{in.} \mathrm{If} \mathrm{the} \mathrm{flat} \mathrm{happens} \mathrm{to} \mathrm{be}$ bowed and not twisted, both the top and bottom readings will be off in the same direction. This measurement is made on flats 1,2 , and 3 .

Specific steps in making the twist measurements are the following:

1. The subassembly lower adapter is clamped in the rotating drive chuck.

2. The welding guide is placed over the top of the subassembly and snapped into location in the fixture. The welding guide unit is raised until the guide is near the top of the hex tubing. The guide must be in contact with three corners of the hex tube for location purposes.

3. The platform holding the dial indicator is placed on the VAD table. The dial indicator should be indicating a reading on the flat of the hex tubing.

4. The subassembly is raised in the VAD until the dial indicator is located about 2 in up from the bottom of the hex tube.

5. The indicator platform is moved until it is approximately parallel with the flats being measured. By moving the indicator from one side of the flat to the other and by using the rotate jog, the indicator may be adjusted to give a near-zero change from one side of the flat to the other.

6. The indicator is moved to the left side of the flat, and its reading is recorded. The indicator is then moved to the right side of the flat, and its reading is recorded.

NOTE: The indicator platform is not moved and the subassembly is not rotated at this point.

7. The subassembly is lowered until the indicator is about 3 in. below the top of the hex tube. Step 6 is then repeated.

8. The subassembly is rotated to the next face, and steps 5 through 7 are repeated.

9. The twist for each of the flats is calculated from the upper and lower measurements. 
C. Button-to-Button Dimensions

Dimensions across the buttons are measured with a snap-gauge equipped with a dial indicator readout. To test the accuracy of the snapgauge, periodic calibrations are made with a 2.318-in. standard. The dimensions across the buttons on flats 1 and 4, 2 and 5 , , and 3 and 6 are measured.

\section{EXPERIMENTAL RESULTS}

The results of the three basic types of measurements described above are cited below.

\section{A. Straightness}

The results (in TIR) of straightness measurements of subassemblies discharged at the end of Run 25 are given in Table I.

The results of straightness measurements of the six control rods discharged from Run 25 are given in Table II.

From an inspection of the data given in Tables I and II, it may be seen that in no case is the tolerance of 0.080 in. for the TIR exceeded.

A demonstration of the accuracy and reproducibility of measurements may be seen in Fig. 6 in which the TIR's for a11 driver subassemblies are plotted as a function of elevation. In most cases, the original flexing attitude of the subassembly is preserved even after long residence times in the core. This feature is most apparent for subassemblies C-270, $\mathrm{C}-275$, and $\mathrm{C}-277$.

On the other hand, relatively large changes in the TIR, though still within tolerance, may be seen for other subassemblies, for example, C-257 and $B-345$. Whether such changes are the consequence of stress release, improper subassembly handling, or bowing forces is not known.

In the case of the six control rods discharged from Run 25, preirradiation tests were conducted on empty hexes with the straightness-testing apparatus described in Section III.A. Postirradiation tests, however, were 
TABLE I. Results of Straightness Measurements of Driver Subassemblies Discharged from Run 25 (TIR Values)

\begin{tabular}{|c|c|c|c|c|c|c|c|}
\hline \multirow{2}{*}{ Subassemb1y } & & \multicolumn{6}{|c|}{ Distance from Top of Hex Tube (in.) } \\
\hline & & 6.000 & 19.25 & 32.50 & 45.875 & 59.125 & 72.50 \\
\hline \multirow[t]{2}{*}{$C-273$} & Pre- & 0.021 & 0.031 & 0.013 & 0.014 & 0.016 & 0.013 \\
\hline & Post- & 0.027 & 0.051 & 0.031 & 0.020 & 0.012 & 0.026 \\
\hline \multirow[t]{2}{*}{$C-274$} & Pre- & 0.036 & 0.054 & 0.034 & 0.024 & 0.012 & 0.014 \\
\hline & Post- & 0.037 & 0.046 & 0.052 & 0.036 & 0.014 & 0.013 \\
\hline \multirow[t]{2}{*}{$C-271$} & Pre- & 0.008 & 0.006 & 0.019 & 0.035 & 0.020 & 0.005 \\
\hline & Post- & 0.009 & 0.013 & 0.020 & 0.049 & 0.026 & 0.018 \\
\hline \multirow[t]{2}{*}{$C-272$} & Pre- & 0.032 & 0.023 & 0.012 & 0.015 & 0.011 & 0.013 \\
\hline & Post- & 0.035 & 0.035 & 0.018 & 0.017 & 0.008 & 0.024 \\
\hline \multirow[t]{2}{*}{$C-275$} & Pre- & 0.028 & 0.030 & 0.023 & 0.019 & 0.010 & 0.015 \\
\hline & Post- & 0.028 & 0.031 & 0.027 & 0.020 & 0.008 & 0.015 \\
\hline \multirow[t]{2}{*}{$C-277$} & Pre- & 0,006 & 0.010 & 0.019 & 0.041 & 0.024 & 0.012 \\
\hline & Post- & 0.004 & 0.008 & 0.022 & 0.046 & 0.027 & 0.016 \\
\hline \multirow[t]{2}{*}{ B-344 } & Pre- & 0.039 & 0.048 & 0.051 & 0.025 & 0.010 & 0.014 \\
\hline & Post- & 0.045 & 0.070 & 0.066 & 0.054 & 0.016 & 0.022 \\
\hline \multirow[t]{2}{*}{$C-257$} & Pre- & 0.022 & 0.015 & 0.003 & 0.013 & 0.004 & 0.016 \\
\hline & Post- & 0.044 & 0.062 & 0.042 & 0.036 & 0.009 & 0.006 \\
\hline \multirow[t]{2}{*}{$B-342$} & Pre- & 0.025 & 0.020 & 0.015 & 0.009 & 0.010 & 0.011 \\
\hline & Post- & 0.024 & 0.022 & 0.033 & 0.034 & 0.016 & 0.011 \\
\hline \multirow[t]{2}{*}{$C-282$} & Pre- & 0.010 & 0.020 & 0.020 & 0.039 & 0.018 & 0.012 \\
\hline & Post- & 0.014 & 0.015 & 0.011 & 0.032 & 0.021 & 0.018 \\
\hline \multirow[t]{2}{*}{$C-262$} & Pre- & 0.016 & 0.024 & 0.021 & 0.034 & 0.014 & 0.023 \\
\hline & Post- & 0.017 & 0.019 & 0.020 & 0.034 & 0.011 & 0.020 \\
\hline \multirow[t]{2}{*}{$B-343$} & Pre- & 0.036 & 0.055 & 0.019 & 0.012 & 0.012 & 0.010 \\
\hline & Post- & 0.050 & 0.075 & 0.056 & 0.022 & 0.004 & 0.016 \\
\hline \multirow[t]{2}{*}{$B-345$} & Pre- & 0.024 & 0.014 & 0.015 & 0.043 & 0.026 & 0.012 \\
\hline & Post- & 0.018 & 0.047 & 0.055 & 0.060 & 0.023 & 0.004 \\
\hline \multirow[t]{2}{*}{$B-346$} & Pre- & 0.033 & 0.024 & 0.009 & 0.017 & 0.009 & 0.024 \\
\hline & Post- & 0.022 & 0.030 & 0.028 & 0.017 & 0.010 & 0.019 \\
\hline
\end{tabular}


Table I, continued

\begin{tabular}{clcccccc} 
& & \multicolumn{5}{c}{ Distance from Top of Hex Tube (in.) } \\
\cline { 3 - 8 } Subassemb1y & & 6.00 & 19.25 & 32.50 & 45.875 & 59.125 & 72.50 \\
\hline \multirow{2}{*}{ B-347 } & Pre- & 0.007 & 0.003 & 0.028 & 0.040 & 0.025 & 0.013 \\
& Post- & 0.012 & 0.018 & 0.051 & 0.066 & 0.034 & 0.022 \\
C-270 & Pre- & 0.016 & 0.021 & 0.015 & 0.012 & 0.006 & 0.026 \\
& Post- & 0.015 & 0.023 & 0.015 & 0.013 & 0.005 & 0.019 \\
C-276 & Pre- & 0.007 & 0.014 & 0.021 & 0.037 & 0.016 & 0.009 \\
& Post- & 0.010 & 0.011 & 0.010 & 0.024 & 0.017 & 0.014
\end{tabular}


TABLE II. Results of Straightness Measurements of Control Rods Discharged from Run 25 (TIR Values)

\begin{tabular}{|c|c|c|c|c|c|c|c|c|c|}
\hline \multirow[b]{3}{*}{ Subassembly } & \multicolumn{6}{|c|}{ Preirradiation } & \multicolumn{3}{|c|}{ Postirradiation } \\
\hline & \multicolumn{3}{|c|}{ Distance from To } & of Hes & \multicolumn{2}{|c|}{ Tube (in.) } & \multicolumn{3}{|c|}{ Location on Hex Tube } \\
\hline & 6.00 & 19.25 & 32.50 & 45.875 & 59.125 & 72.50 & $\begin{array}{l}6 \text { in. } \\
\text { from Top } \\
\end{array}$ & $\begin{array}{l}6 \text { in. from } \\
\text { Midpoint }\end{array}$ & $\begin{aligned} & 3 \text { in. } \\
& \text { from Bottom } \\
&\end{aligned}$ \\
\hline$L-432$ & 0.015 & 0.017 & 0.013 & 0.016 & 0.002 & 0.013 & 0.037 & 0.036 & 0.036 \\
\hline$L-435$ & 0.010 & 0.014 & 0.008 & 0.011 & 0.004 & 0.034 & 0.051 & 0.013 & 0.081 \\
\hline$L-437$ & 0.009 & 0.022 & 0.020 & 0.028 & 0.003 & 0.031 & 0.037 & 0.030 & 0.039 \\
\hline$L-438$ & 0.017 & 0.015 & 0.008 & 0.004 & 0.003 & 0.045 & 0.042 & 0.027 & 0.029 \\
\hline$L-440$ & 0.015 & 0.028 & 0.015 & 0.027 & 0.004 & 0.022 & 0.035 & 0.012 & 0.007 \\
\hline $\mathrm{L}-441$ & 0.012 & 0.013 & 0.014 & 0.028 & 0.002 & 0.011 & 0.031 & 0.026 & 0.042 \\
\hline
\end{tabular}



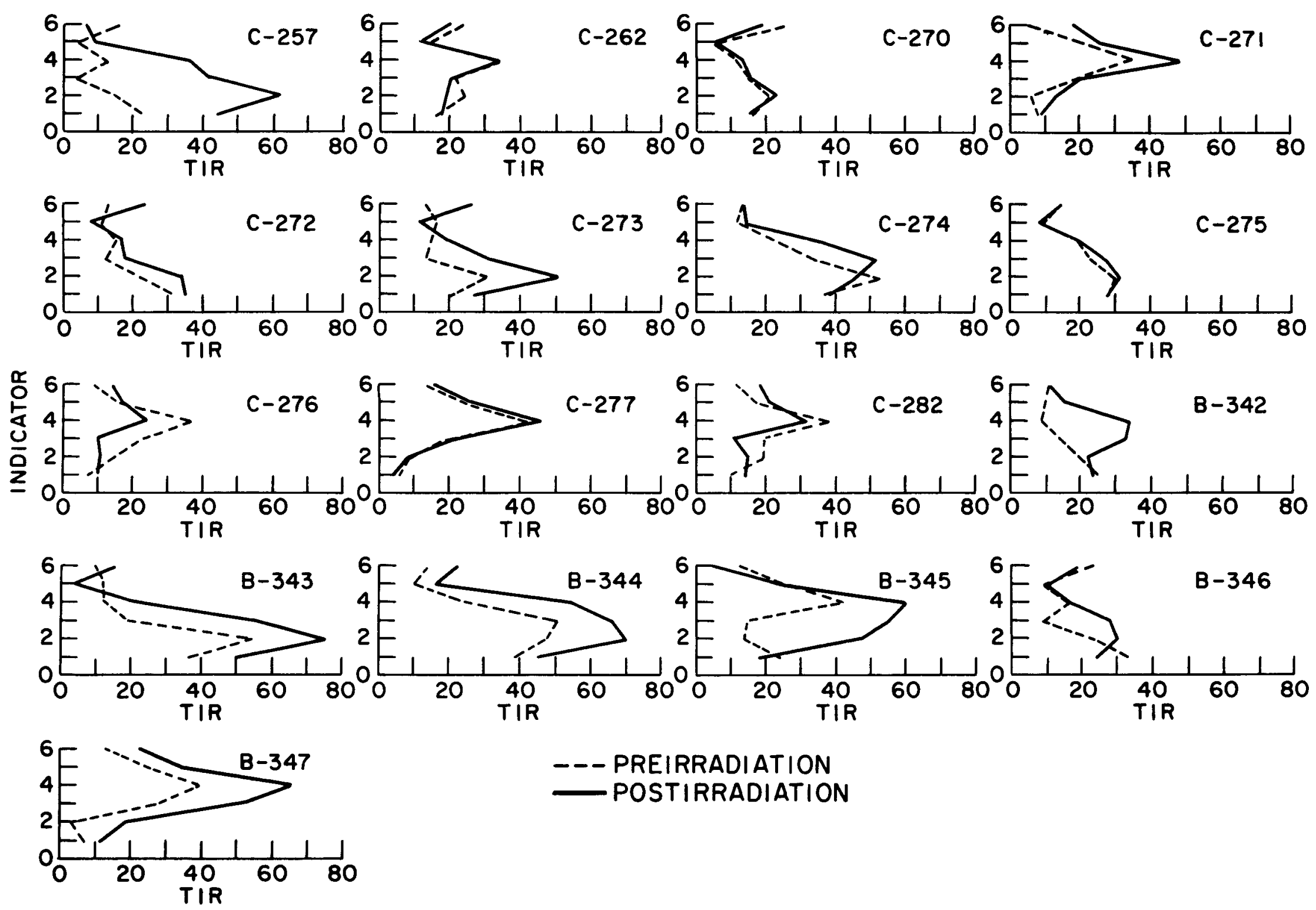

Fig. 6. Results of Straightness Measurements of Driver Subassemblies Discharged from Run 25 
conducted on complete subassemblies in the VAD. For the latter, the TIR was measured approximately 6 in. from the top, at midpoint, and approximately 3 in. from the bottom. Since control subassemblies are not equipped with spacer buttons, postirradiation studies were limited to measurements of straightness and twist.

\section{B. $\quad$ Twist}

The results of twist measurements of both driver and control-rod subassemblies discharged at the end of Run 25 are given in Table III. These may be compared with a permissible maximum twist of 0.023 in., which corresponds to an angular twist of $1^{\circ}$

Actual values of the preirradiation results are given in Table III for some subassemblies. In these particular instances, the value cited is the maximum value recorded for the three flats examined.

\section{Button-to-Button Dimensional Measurements, Run 25}

The results of measurements conducted across opposite buttons on driver subassemblies are summarized in Table IV. The results cited are to be compared with the tolerance limits of $2.318 \pm 0.001 \mathrm{in}$. As the consequence of a large number of button-to-button dimensional checks, the reproducibility of such measurements is estimated to be approximately \pm 0.001 in.

D. Button-to-Button Dimensional Measurements, Run 26

Since the results of straightness and twist tests conducted on subassemblies discharged from Run 25 indicated little or no significant change as a consequence of residence in the core, such measurements were not made on subassemblies discharged from Run 26. Dimensional checks across the spacer buttons, however, were considered necessary since the results of Run-25 tests did indeed indicate significant changes in button-to-button dimensions.

The results of button-to-button measurements made on driver subassemblies discharged at the end of Run 26 are summarized in Table $V$. 
TABLE III. Results of Twist Measurements of Driver and Control-rod Subassemblies Discharged from Run 25

Subassembly

C-273

Flat

No.

1

2

3

C-274

C-271

C-275

$C-277$

$C-282$
1

2

3

1

2

3

1

2

3

1

2

3

1

2

3

1

2

3

1

2

3

1

2

3

1

2

3

$\frac{\begin{array}{l}\text { Preirradiation* } \\ \text { (in.) }\end{array}}{\text { (in. }}$

In spec.

In spec.

Postirradiation*

(in.)

0.007

0.002

0.000

0.003

0.004

0.001

In spec.

0.010

0.004

0.014

In spec.

0.003

0.000

0.005

In spec.

0.006

0.010

0.000

In spec.

0.003

0.005

0.001

In spec。

0.008

0.020

0.011

In spec.

0.009

0.010

0.003

0.025

0.020

0.000

0.008

In spec.

0.010

0.005

0.014

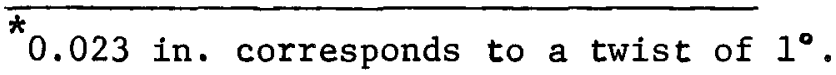


Table III, continued

\begin{tabular}{|c|c|c|c|}
\hline Subassemb:1y & $\begin{array}{l}\text { Flat } \\
\text { No. }\end{array}$ & $\begin{array}{l}\text { Preirradiation * } \\
\text { (in.) }\end{array}$ & $\begin{array}{l}\text { Postirradiation * } \\
\text { (in.) }\end{array}$ \\
\hline \multirow[t]{3}{*}{$C-262$} & 1 & 0.005 & 0.003 \\
\hline & 2 & & 0.011 \\
\hline & 3 & & 0.001 \\
\hline \multirow[t]{3}{*}{ B-343 } & 1 & 0.005 & 0.007 \\
\hline & 2 & & 0.006 \\
\hline & 3 & & 0.006 \\
\hline \multirow[t]{3}{*}{$B-345$} & 1 & 0.012 & 0.004 \\
\hline & 2 & & 0.000 \\
\hline & 3 & & 0.001 \\
\hline \multirow[t]{3}{*}{ B-346 } & 1 & 0.028 & 0.004 \\
\hline & 2 & & 0.007 \\
\hline & 3 & & 0.003 \\
\hline \multirow[t]{3}{*}{$c-276$} & 1 & 0.009 & 0.010 \\
\hline & 2 & & 0.007 \\
\hline & 3 & & 0.003 \\
\hline \multirow[t]{3}{*}{ B-347 } & 1 & 0.010 & 0.000 \\
\hline & 2 & & 0.002 \\
\hline & 3 & & 0.003 \\
\hline \multirow[t]{3}{*}{$C-270$} & 1 & In spec. & 0.004 \\
\hline & 2 & & 0.002 \\
\hline & 3 & & 0.005 \\
\hline \multirow[t]{3}{*}{$L-432$} & 1 & 0.005 & 0.001 \\
\hline & 2 & & 0.003 \\
\hline & 3 & & 0.004 \\
\hline \multirow[t]{3}{*}{$L-435$} & 1 & 0.009 & 0.003 \\
\hline & 2 & & 0.003 \\
\hline & 3 & & 0.001 \\
\hline \multirow[t]{3}{*}{$L-437$} & 1 & 0.015 & 0.002 \\
\hline & 2 & & 0.001 \\
\hline & 3 & & 0.000 \\
\hline \multirow[t]{3}{*}{$L-438$} & 1 & 0.004 & 0.004 \\
\hline & 2 & & 0.001 \\
\hline & 3 & & 0.002 \\
\hline
\end{tabular}

*0.023 in. corresponds to a twist of $1^{\circ}$. 
Table III, continued

\begin{tabular}{ccc} 
Subassemb1y & $\begin{array}{l}\text { Flat } \\
\text { No. }\end{array}$ & $\begin{array}{c}\text { Preirradiation* } \\
\text { (in.) }\end{array}$ \\
\cline { 2 - 3 } & 1 & 0.008 \\
L-440 & 3 & \\
& 3 & 0.015 \\
& 1 & \\
& 3 &
\end{tabular}

\begin{tabular}{c}
$\begin{array}{c}\text { Postirradiation* } \\
\text { (in.) }\end{array}$ \\
\hline 0.004 \\
0.001 \\
0.001 \\
0.002 \\
0.001 \\
0.004
\end{tabular}

${ }^{\star} 0.023$ in. corresponds to a twist of $1^{\circ}$. 
TABLE IV. Results of Button-to-Button Measurements of Driver Subassemblies Discharged from Run 25

\begin{tabular}{|c|c|c|c|c|}
\hline Subassembly & Flats & $\begin{array}{l}\text { Preirradiation } \\
\text { (in.) } \\
\end{array}$ & $\begin{array}{l}\text { Postirradiation } \\
\text { (in.) } \\
\end{array}$ & $\begin{array}{c}\text { Deviation } \\
\text { (in.) }\end{array}$ \\
\hline \multirow[t]{3}{*}{$C-273$} & $1-4$ & One set 2.316 & 2.316 & -0.002 \\
\hline & $2-5$ & Others in spec. & 2.309 & -0.007 \\
\hline & $3-6$ & & 2.311 & -0.007 \\
\hline \multirow[t]{3}{*}{$C-274$} & $1-4$ & One set 2.316 & 2.312 & -0.006 \\
\hline & $2-5$ & Others in spec. & 2.324 & +0.006 \\
\hline & $3-6$ & & 2.310 & -0.006 \\
\hline \multirow[t]{3}{*}{$C-271$} & $1-4$ & In spec. & 2.319 & +0.001 \\
\hline & $2-5$ & & 2.315 & -0.003 \\
\hline & $3-6$ & & 2.317 & -0.001 \\
\hline \multirow[t]{3}{*}{$C-272$} & $1-4$ & In spec. & 2.317 & -0.001 \\
\hline & $2-5$ & & 2.316 & -0.002 \\
\hline & $3-6$ & & 2.322 & +0.004 \\
\hline \multirow[t]{3}{*}{$C-275$} & $1-4$ & One set 2.314 & 2.311 & -0.003 \\
\hline & $2-5$ & Others in spec. & 2.321 & +0.003 \\
\hline & $3-6$ & & 2.320 & +0.002 \\
\hline \multirow[t]{3}{*}{$C-277$} & $1-4$ & One set 2.314 & 2.312 & -0.002 \\
\hline & $2-5$ & Others in spec. & 2.316 & -0.002 \\
\hline & $3-6$ & & 2.315 & -0.003 \\
\hline \multirow[t]{3}{*}{$B-344$} & $1-4$ & One set 2.323 & 2.316 & -0.002 \\
\hline & $2-5$ & Others in spec. & 2.321 & -0.002 \\
\hline & $3-6$ & & 2.318 & 0.000 \\
\hline \multirow[t]{3}{*}{$C-257$} & $1-4$ & In spec. & 2.320 & +0.002 \\
\hline & $2-5$ & & 2.319 & +0.001 \\
\hline & $3-6$ & & 2.317 & -0.001 \\
\hline \multirow[t]{3}{*}{$B-342$} & $1-4$ & One set 2.320 & 2.319 & -0.001 \\
\hline & $2-5$ & Others in spec. & 2.311 & -0.007 \\
\hline & $3-6$ & & 2.311 & -0.007 \\
\hline \multirow[t]{3}{*}{$C-282$} & $1-4$ & In spec. & 2.316 & -0.002 \\
\hline & $2-5$ & & 2.320 & +0.002 \\
\hline & $3-6$ & & 2.320 & +0.002 \\
\hline \multirow[t]{3}{*}{$c-262$} & $1-4$ & In spec. & 2.324 & +0.006 \\
\hline & $2-5$ & & 2.321 & +0.003 \\
\hline & $3-6$ & & 2.319 & +0.001 \\
\hline
\end{tabular}


Table IV, continued

\begin{tabular}{|c|c|c|c|c|}
\hline Subassembly & Flats & $\begin{array}{l}\text { Preirradiation } \\
\text { (in.) } \\
\end{array}$ & $\begin{array}{c}\text { Postirradiation } \\
\text { (in.) }\end{array}$ & $\begin{array}{c}\text { Deviation } \\
\text { (in.) } \\
\end{array}$ \\
\hline \multirow[t]{3}{*}{$B-343$} & $1-4$ & One set 2.323 & 2.317 & -0.001 \\
\hline & $2-5$ & Others in spec. & 2.321 & -0.002 \\
\hline & $3-6$ & & 2.315 & -0.003 \\
\hline \multirow[t]{3}{*}{ B-345 } & $1-4$ & One set 2.321 & 2.319 & -0.002 \\
\hline & $2-5$ & Others in spec. & 2.318 & 0.000 \\
\hline & $3-6$ & & 2.315 & -0.003 \\
\hline \multirow[t]{3}{*}{$B-346$} & $1-4$ & One set 2.322 & 2.316 & -0.002 \\
\hline & $2-5$ & Others in spec. & 2.318 & -0.004 \\
\hline & $3-6$ & & 2.318 & 0.000 \\
\hline \multirow[t]{3}{*}{$C-276$} & $1-4$ & One set 2.321 & 2.315 & -0.003 \\
\hline & $2-5$ & Others in spec. & 2.315 & -0.003 \\
\hline & $3-6$ & & 2.318 & -0.003 \\
\hline \multirow[t]{3}{*}{$B-347$} & $1-4$ & In spec. & 2.321 & +0.003 \\
\hline & $2-5$ & & 2.317 & -0.001 \\
\hline & $3-6$ & & 2.318 & 0.000 \\
\hline \multirow[t]{3}{*}{$C-270$} & $1-4$ & One set 2.315 & 2.314 & -0.001 \\
\hline & $2-5$ & Others in spec. & 2.317 & -0.001 \\
\hline & $3-6$ & & 2.316 & -0.002 \\
\hline
\end{tabular}


TABLE V. Results of Button-to-Button Measurements of Driver Subassemblies Discharged from Run 26

\begin{tabular}{|c|c|c|c|c|}
\hline Subassemb1y & Flats & $\begin{array}{l}\text { Preirradiation } \\
\text { (in。) } \\
\end{array}$ & $\begin{array}{l}\text { Postirradiation } \\
\text { (in。) } \\
\end{array}$ & $\begin{array}{l}\text { Deviation } \\
\text { (in.) } \\
\end{array}$ \\
\hline \multirow[t]{3}{*}{$B-349$} & $1-4$ & One set 2.321 & 2.315 & -0.003 \\
\hline & $2-5$ & Others in spec. & 2.313 & -0.005 \\
\hline & $3-6$ & & 2.318 & -0.003 \\
\hline \multirow[t]{3}{*}{$B-350$} & $1-4$ & One set 2.321 & 2.316 & -0.002 \\
\hline & $2-5$ & Others in spec. & 2.317 & -0.001 \\
\hline & $3-6$ & & 2.322 & +0.001 \\
\hline \multirow[t]{3}{*}{$B-351$} & $1-4$ & One set 2.320 & 2.318 & 0.000 \\
\hline & $2-5$ & Others in spec. & 2.322 & +0.002 \\
\hline & $3-6$ & & 2.318 & 0.000 \\
\hline \multirow[t]{3}{*}{$B-353$} & $1-4$ & One set 2.319 & 2.312 & -0.007 \\
\hline & $2-5$ & Others in spec. & 2.305 & -0.013 \\
\hline & $3-6$ & & 2.311 & -0.007 \\
\hline \multirow[t]{3}{*}{$C-265$} & $1-4$ & One set 2.315 & 2.317 & -0.001 \\
\hline & $2-5$ & Others in spec. & 2.322 & +0.004 \\
\hline & $3-6$ & & 2.313 & -0.002 \\
\hline \multirow[t]{3}{*}{$C-292$} & $1-4$ & In spec. & 2.316 & -0.002 \\
\hline & $2-5$ & & 2.315 & -0.003 \\
\hline & $3-6$ & & 2.319 & +0.001 \\
\hline \multirow[t]{3}{*}{$c-296$} & $1-4$ & One set 2.316 & 2.312 & -0.004 \\
\hline & $2-5$ & Others in Spec. & 2.321 & +0.003 \\
\hline & $3-6$ & & 2.318 & 0.000 \\
\hline \multirow[t]{3}{*}{$C-297$} & $1-4$ & One set 2.316 & 2.320 & +0.002 \\
\hline & $2-5$ & Others in spec. & 2.315 & -0.001 \\
\hline & $3-6$ & & 2.315 & -0.003 \\
\hline \multirow[t]{3}{*}{$C-2025$} & $1-4$ & In spec. & 2.319 & +0.001 \\
\hline & $2-5$ & & 2.316 & -0.002 \\
\hline & $3-6$ & & 2.313 & -0.005 \\
\hline \multirow[t]{3}{*}{$C-2035$} & $1-4$ & In spec. & 2.313 & -0.005 \\
\hline & $2-5$ & & 2.314 & -0.004 \\
\hline & $3-6$ & & 2.316 & -0.002 \\
\hline
\end{tabular}


Table V, continued

\begin{tabular}{|c|c|c|c|c|}
\hline Subassembly & Flats & $\begin{array}{l}\text { Preirradiation } \\
\text { (in.) } \\
\end{array}$ & $\begin{array}{l}\text { Postirradiation } \\
\text { (in.) }\end{array}$ & $\begin{array}{c}\text { Deviation } \\
\text { (in.) } \\
\end{array}$ \\
\hline \multirow[t]{3}{*}{$C-298$} & $1-4$ & In spec. & 2.315 & -0.003 \\
\hline & $2-5$ & & 2.322 & +0.004 \\
\hline & $3-6$ & & 2.318 & 0.000 \\
\hline \multirow[t]{3}{*}{$C-2028$} & $1-4$ & In spec. & 2.316 & -0.002 \\
\hline & $2-5$ & & 2.322 & +0.004 \\
\hline & $3-6$ & & 2.320 & +0.002 \\
\hline \multirow[t]{3}{*}{$C-2030$} & $1-4$ & In spec. & 2.321 & +0.003 \\
\hline & $2-5$ & & 2.316 & -0.002 \\
\hline & $3-6$ & & 2.314 & -0.004 \\
\hline \multirow[t]{3}{*}{ C-2039 } & $1-4$ & In spec. & 2.320 & +0.002 \\
\hline & $2-5$ & & 2.318 & 0.000 \\
\hline & $3-6$ & & 2.319 & +0.001 \\
\hline \multirow[t]{3}{*}{$B-348$} & $1-4$ & In spec. & 2.315 & -0.003 \\
\hline & $2-5$ & & 2.317 & -0.001 \\
\hline & $3-6$ & & 2.326 & +0.008 \\
\hline \multirow[t]{3}{*}{$C-286$} & $1-4$ & In spec. & 2.312 & -0.006 \\
\hline & $2-5$ & & 2.313 & -0.005 \\
\hline & $3-6$ & & 2.321 & +0.003 \\
\hline \multirow[t]{3}{*}{$C-287$} & $1-4$ & In spec. & 2.313 & -0.005 \\
\hline & $2-5$ & & 2.324 & +0.006 \\
\hline & $3-6$ & & 2.311 & -0.007 \\
\hline \multirow[t]{3}{*}{$C-293$} & $1-4$ & One set 2.311 & 2.313 & -0.005 \\
\hline & $2-5$ & Others in spec. & 2.317 & -0.001 \\
\hline & $3-6$ & & 2.310 & -0.001 \\
\hline \multirow[t]{3}{*}{$C-299$} & $1-4$ & In spec. & 2.315 & -0.003 \\
\hline & $2-5$ & & 2.317 & -0.001 \\
\hline & $3-6$ & & 2.316 & -0.002 \\
\hline \multirow[t]{3}{*}{ U-1495* } & $1-4$ & Unavailable & 2.317 & \\
\hline & $2-5$ & & 2.317 & \\
\hline & $3-6$ & & 2.318 & \\
\hline
\end{tabular}

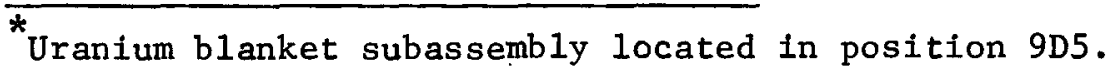


Table V, continued

\begin{tabular}{|c|c|c|c|c|}
\hline Subassembly & Flats & $\begin{array}{l}\text { Preirradiation } \\
\text { (in.) } \\
\end{array}$ & $\begin{array}{c}\text { Postirradiation } \\
\text { (in.) }\end{array}$ & $\begin{array}{c}\text { Deviation } \\
\text { (in.) }\end{array}$ \\
\hline \multirow[t]{3}{*}{$C-294$} & $1-4$ & \multirow[t]{3}{*}{ In spec. } & 2.318 & 0.000 \\
\hline & $2-5$ & & 2.311 & -0.007 \\
\hline & $3-6$ & & 2.310 & -0.008 \\
\hline \multirow[t]{3}{*}{$C-2002$} & $1-4$ & \multirow[t]{3}{*}{ In spec。 } & 2.316 & -0.002 \\
\hline & $2-5$ & & 2.313 & -0.005 \\
\hline & $3-6$ & & 2.320 & +0.002 \\
\hline \multirow[t]{3}{*}{$C-2004$} & $1-4$ & \multirow[t]{3}{*}{ In spec. } & 2.319 & +0.001 \\
\hline & $2-5$ & & 2.316 & -0.002 \\
\hline & $3-6$ & & 2.321 & +0.003 \\
\hline \multirow[t]{3}{*}{ B-355 } & $1-4$ & One set 2.320 & 2.322 & +0.002 \\
\hline & $2-5$ & \multirow[t]{2}{*}{ Others in spec. } & 2.315 & -0.003 \\
\hline & $3-6$ & & 2.313 & -0.005 \\
\hline \multirow[t]{3}{*}{$B-357$} & $1-4$ & One set 2.320 & 2.318 & 0.000 \\
\hline & $2-5$ & \multirow[t]{2}{*}{ Others in spec. } & 2.322 & +0.002 \\
\hline & $3-6$ & & 2.322 & +0.004 \\
\hline \multirow[t]{3}{*}{$\mathrm{B}-358$} & $1-4$ & One set 2.320 & 2.322 & +0.002 \\
\hline & $2-5$ & \multirow[t]{2}{*}{ Others in spec. } & 2.321 & +0.003 \\
\hline & $3-6$ & & 2.322 & +0.004 \\
\hline \multirow[t]{3}{*}{$C-2077$} & $1-4$ & \multirow[t]{3}{*}{ In spec. } & 2.318 & 0.000 \\
\hline & $2-5$ & & 2.320 & +0.002 \\
\hline & $3-6$ & & 2.324 & +0.006 \\
\hline \multirow[t]{3}{*}{$\mathrm{XGO5*}$} & $1-4$ & \multirow[t]{3}{*}{ Unavailable } & 2.317 & \\
\hline & $2-5$ & & 2.322 & \\
\hline & $3-6$ & & 2.316 & \\
\hline \multirow[t]{3}{*}{ B-352 } & $1-4$ & One set 2.320 & 2.314 & -0.004 \\
\hline & $2-5$ & \multirow[t]{2}{*}{ Others in spec. } & 2.317 & -0.001 \\
\hline & $3-6$ & & 2.321 & +0.001 \\
\hline \multirow[t]{3}{*}{$C-2036$} & $1-4$ & \multirow[t]{3}{*}{ In spec. } & 2.311 & -0.007 \\
\hline & $2-5$ & & 2.310 & -0.008 \\
\hline & $3-6$ & & 2.320 & +0.002 \\
\hline
\end{tabular}

*Irradiation subassembly. 
Table V, continued

\begin{tabular}{|c|c|c|c|c|}
\hline Subassembly & Flats & $\begin{array}{l}\text { Preirradiation } \\
\text { (in.) }\end{array}$ & $\begin{array}{l}\text { Postirradiation } \\
\text { (in.) }\end{array}$ & $\begin{array}{c}\text { Deviation } \\
\text { (in.) }\end{array}$ \\
\hline \multirow[t]{3}{*}{$C-2005$} & $1-4$ & \multirow[t]{3}{*}{ In spec. } & 2.316 & -0.002 \\
\hline & $2-5$ & & 2.318 & -0.003 \\
\hline & $3-6$ & & 2.319 & +0.001 \\
\hline \multirow[t]{3}{*}{ B-354 } & $1-4$ & One set 2.319 & 2.319 & 0.000 \\
\hline & $2-5$ & \multirow[t]{2}{*}{ Others in spec. } & 2.319 & +0.001 \\
\hline & $3-6$ & & 2.315 & -0.003 \\
\hline \multirow[t]{3}{*}{$C-295$} & $1-4$ & One set 2.313 & 2.313 & -0.005 \\
\hline & $2-5$ & \multirow[t]{2}{*}{ Others in spec. } & 2.308 & -0.005 \\
\hline & $3-6$ & & 2.311 & -0.007 \\
\hline \multirow[t]{3}{*}{ B-359 } & $1-4$ & One set 2.320 & 2.320 & +0.002 \\
\hline & $2-5$ & \multirow[t]{2}{*}{ Others in spec. } & 2.324 & +0.004 \\
\hline & $3-6$ & & 2.317 & -0.001 \\
\hline \multirow[t]{3}{*}{$\mathrm{x} 030 *$} & $1-4$ & \multirow[t]{3}{*}{ Unavailable } & 2.320 & \\
\hline & $2-5$ & & 2.318 & \\
\hline & $3-6$ & & 2.319 & \\
\hline
\end{tabular}


Values given in the righthand columns of Tables IV and $V$ are the results of attempts to establish significant deviations from the results of preirradiation measurements. In some cases, original measurements indicated that one set of flats was either over or under the nominal specification of $2.318 \pm 0.001$ in. Recognition of this fact is considered by comparing an original under-specification measurement with the smallest dimension measured across all three sets of flats after irradiation. Conversely, original over-specification measurements are compared with the largest dimension measured across all three flats after irradiation. For example, consider the results for subassembly C-273 given in Table IV. In this case it has been assumed that the original under-specification value of 2.316 in. was measured between flats 2 and 5 since the lowest postirradiation value for the three flats was measured between flats 2 and 5 . Hence the decrease noted in the last column between flats 2 and 5 is referenced against the 2.316 in. value rather than against the nominal specification of $2.318 \mathrm{in.}$ For the remaining two sets of flats, i.e. 1 and 4 and 3 and 6 , the reference value is the nominal specification value of 2.318 in. since these sets of flats were assumed to be within spectfication.

Similar logic was used in establishing deviations for those cases in which the out-of-specification value was larger than the nominal value. For example, consider subassembly B-344 in Table IV. In this case it was assumed that the distance between flats 1 and 4 decreased from an initial value of $2.323 \mathrm{in.}$ to a final value of $2.321 \mathrm{in}$.

of the 51 individual measurements made of the 17 subassemblies discharged from Run 25, 34 indicated a decrease, 4 indicated no change, and only 13 indicated an increase. The total decrease (the sum of all decreases) was $0.099 \mathrm{in.}$, and the corresponding total increase was 0.039 in. Accordingly, the average algebraic change may be shown to be $-0.001_{2}$ in. per flat.

For Run 26, much the same pattern was found. Of a total of 96 measurements of 32 subassemblies, 54 registered a decrease, 9 no change, and 33 registered increases. The total decrease was $0.024 \mathrm{in}$, and the total increase was $0.090 \mathrm{in}$. The average algebraic change per flat was found to be (coincidentally) $-0.001_{2}$ in. 
Pictorial illustrations of the results of the button-to-button dimensional studies for Runs 25 and 26 are given in Figs. 7 and 8, respectively. In assembling the information illustrated in these figures, care was taken to preserve the relative orientation of all subassemblies with respect to each other and with respect to the geometric center of the core. Preservation of orientation was guided by Identification notches machined into the lower adapters. The locations of experimental subassembly experiments, control rods, and remaining driver subassemblies for the Run-25 and Run-26 loadings are designated in Figs. 3 and 4, respectively: In both runs, control-rod No. 1 was replaced by a special stainless steel drop rod; in Run 26, contro1rod No. 8 was replaced with an oscillator rod.

\section{EFFECTS OF STRESS RELIEF THROUGH HEATING}

To establish the effects of heating on the deformation of subassemblies, two experiments were conducted. In one, careful measurements were made across the flats of a special subassembly (X900) used in a study of sodium immersion-water wash effects. The subassembly was "soaked" for 15 days in $700^{\circ} \mathrm{F}$ sodium in the storage basket during Run 26. The dimensions across the buttons were remeasured following discharge. For all flats a net increase of 3 mils was noted.

In another series of tests, three hex sections containing spacer buttons were heated in a furnace for $3 \mathrm{hr}$ at $900^{\circ} \mathrm{F}$ and then air cooled. The results of measurements conducted across the buttons indicated that the average increase across the nine sets of flats was $0.002 \mathrm{in}$. In no case was a decrease noted. These results indicate that stress relief through heating is manifested by dimensional increases and imply that the decreases in button-to-button dimensions noted for Run-25 and Run-26 subassemblies are very likely real.

\section{SIGNIFICANCE OF STRAIGHTNESS AND TWIST TEST RESULTS}

From an inspection of straightness data summarized in tabular form in Table I and in graphical form in Fig. 6, it may be concluded that of the 


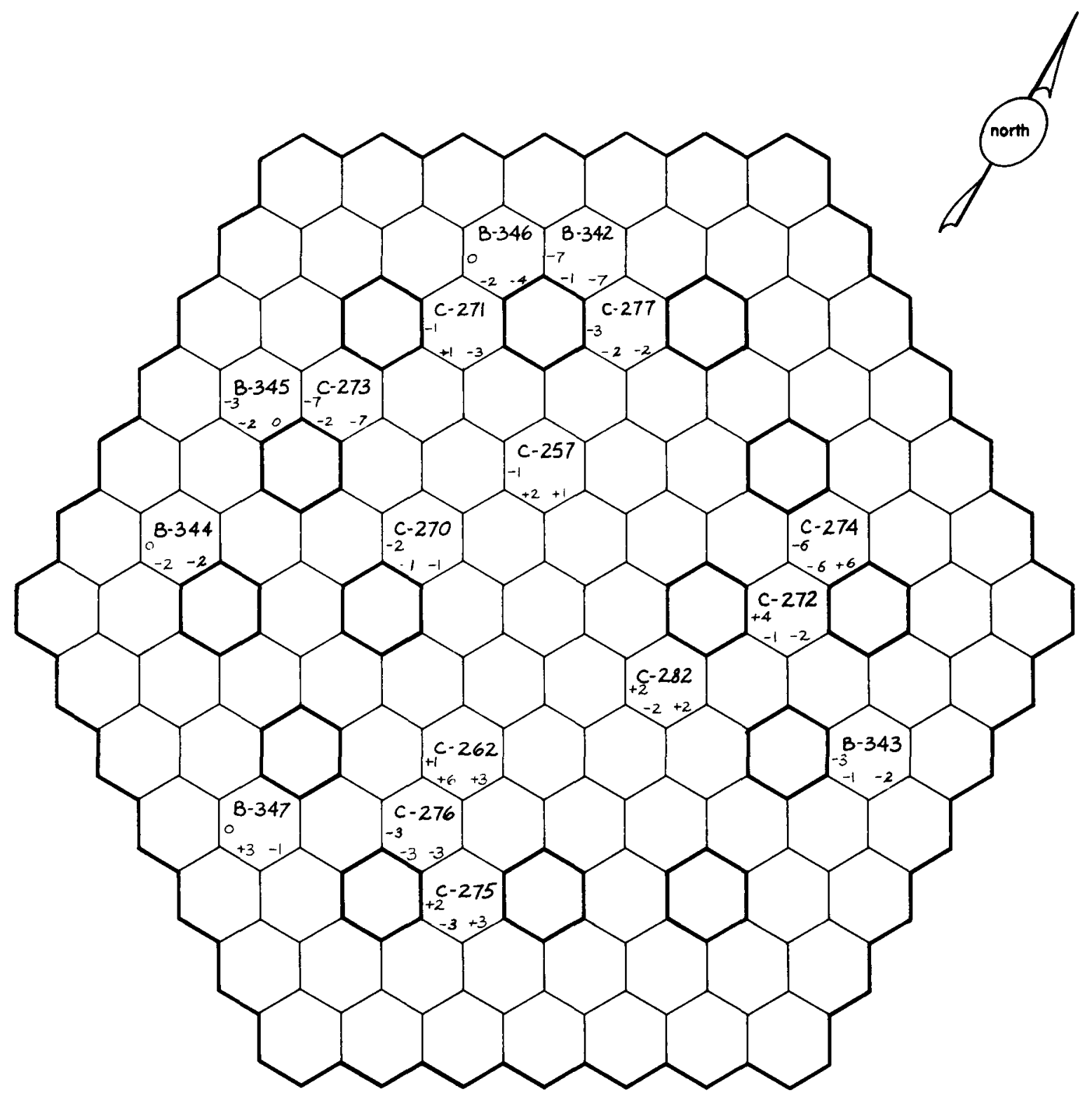

Fig. 7. Deviations Calculated from Button-to-Button Measurements, Run 25 


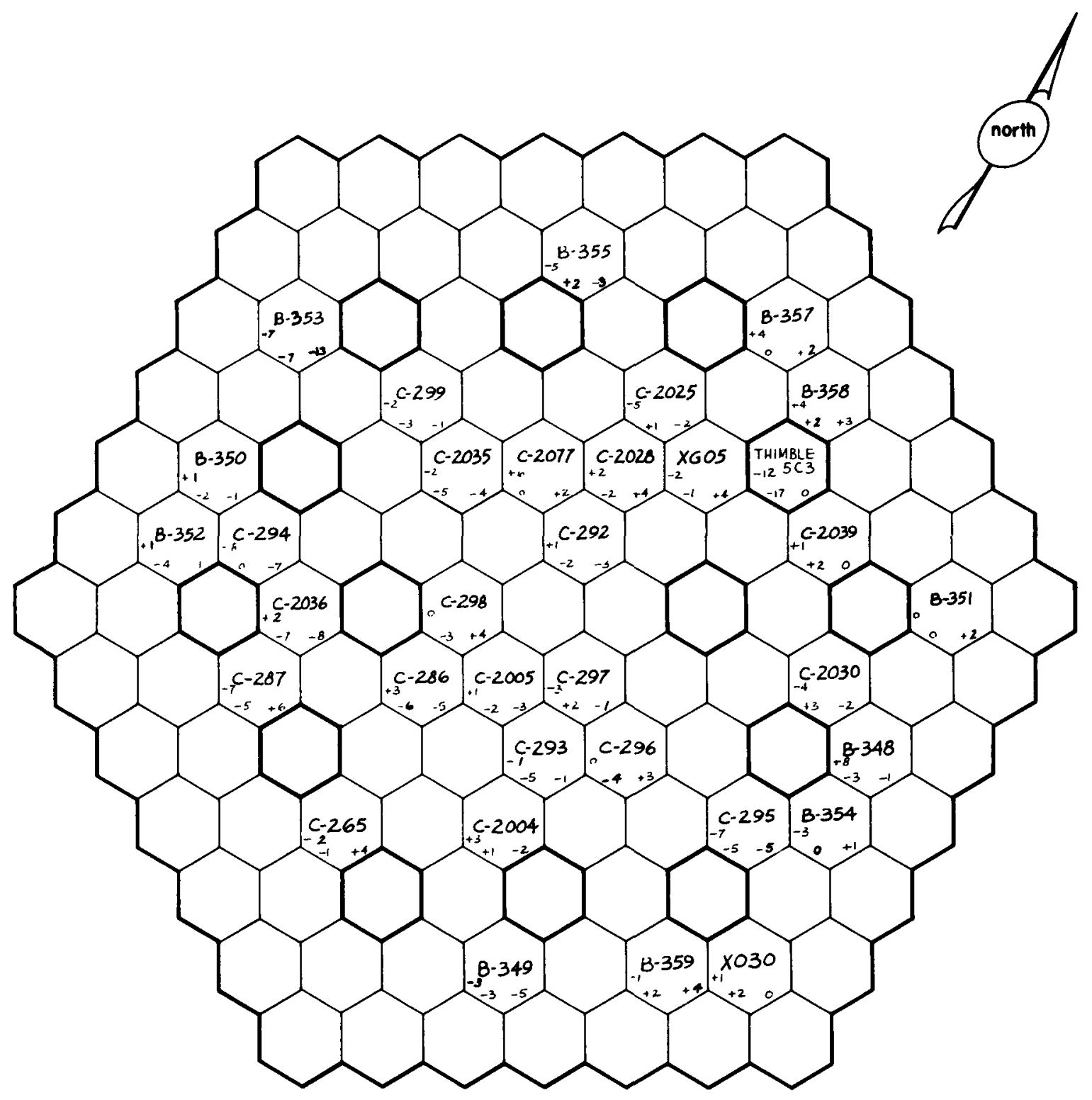

Fig. 8. Deviations Calculated from Button-to-Button Measurements, Run 26C 
17 fuel subassemblies discharged from Run 25, only two (C-257 and C-275) were significantly bent either as a consequence of their residence in the core or as the result of handling operations. Even in these two isolated instances, however, the extent of bending was still less than the 80-mil TIR permissible variation. While failing to demonstrate the existence of significant bending effects as a consequence of in-core residence, the results of the straightness tests, as illustrated in Fig. 6, do demonstrate the reliability of the test procedure.

From an examination of the results of twist measurements, summarized in Table III, it may be seen that in the worst cases, those for postirradiation measurements of subassemblies B-344 and B-342, the twist amounted to $0.020 \mathrm{in.}$ or approximately $0.9^{\circ}$, a value less than the original specification. For some subassemblies, maximum values established in preirradiation studies are cited. A comparison of such values with the results of postirradiation measurements, however, fails to reveal any meaningful correlation between pre- and postirradiation results. The fact that some subassemblies apparently leave the core with less twist than they had when they were inserted very likely reflects the degree of uncertainty associated with twist measurements.

Thus, from a survey of the results conducted for twist and straightness before and after irradiation, it may be concluded that subassemblies are not undergoing any perceptible change in straightness and twist as a consequence of irradiation.

\section{SIGNIFICANCE OF BUTTON-TO-BUTTON DIMENSIONAL CHANGES}

Although no evidence exists to indicate any significant or even perceptible change in straightness or twist, evidence does exist to indicate that compressional forces are apparently large enough to cause plastic deformational effects in the vicinity of the spacer buttons. As cited above, the number of flats that decreased in dimensions across the buttons exceeds the number that increased. In view of the results of the stress-relief experiments, which indicated dimensional increases under elevated temperature 
conditions, it seems reasonable to conclude that the compressional effects noted are real. It is also reasonable to assume that the extent of compression is probably greater than the results imply since compressional effects across some of the flats may have been masked by stress relief under high-temperature conditions.

It is possible, of course, that the compressional effects noted may be the result of strong bowing forces which, in turn, originate from strong temperature gradients across core components. Because the core contains a wide variety of units--for example, driver subassemblies, control rods, experimental subassemblies, half-fueled driver subassemblies, drop rod, etc.--complex subassembly bowing attitudes must be expected. An attempt has been made to correlate the extent and directional aspects of compressional effects with forces that act inward from the radial reflector. No evidence of a correlation could be found.

It is also possible that similar deformational effects have always existed; but, since comparable previous data are nonexistent, it cannot be concluded that deformational phenomena are peculiar to Run 25.

The immediate and long-term implications of subassembly deformational effects in the vicinity of the buttons are clear. Whenever additional clearances are provided between fuel subassemblies, additional mechanical movements are possible. These, in turn, may be manifested through fuel movement in the form of strong ehanges in the-magnitude and power-dependency of the power coefficient. It is conceivable-that increased clearance systems caused by subassembly compression may ultimately be associated with the marked changes noted in the power coefficient following the installation of the stainless steel reflector. 


\section{REFERENCES}

1. Cushman, R. A., "The Effect of Radial Heat Transfer on the Temperature Distribution in EBR-II Stainless-Steel Reflector Subassemblies," Transactions American Nuclear Society, 10 (2), p. 661 (Nov. 1967).

2. Bump, T. R., "Effect of Reactor Temperatures on Bowing of EBR-II Subassemb1ies," Transactions American Nuclear Society, 10 (2), p. 661 (Nov. 1967).

3. Koch, L. J..et al., Hazard Summary Report, Experimental Breeder Reactor II (EBR-II), ANL-5719 (May 1957). 